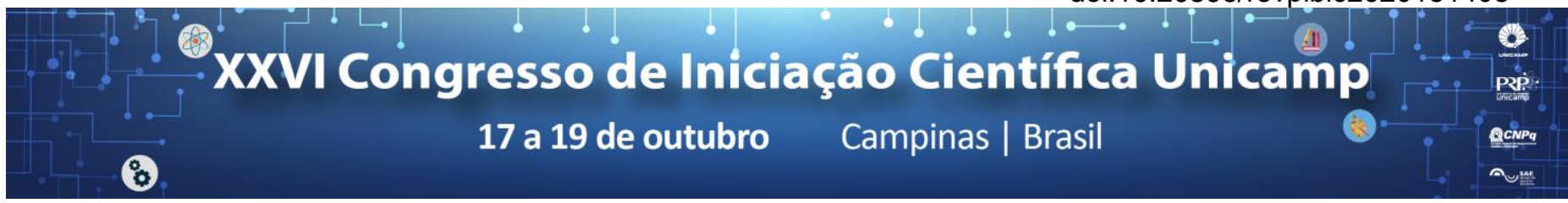

\title{
Avaliação da atividade antimicrobiana de diferentes enxaguantes bucais frente à bacterias orais
}

\author{
Ana C. Nalin*, Gabriel F. Sunhiga, Samira M. N. Hernandes, Maicon R. Z. Passini, Brenda, B.P.F.A Gomes
}

\section{Resumo}

As bactérias presentes na cavidade bucal podem causar efeitos danosos ao se aderirem aos dentes. Visando auxiliar a eliminação destes microrganismos surgiram os enxaguatórios bucais. Considerando a importância dos enxaguatórios na higiene bucal, este estudo teve como objetivo avaliar a atividade antimicrobiana de diferentes enxaguatório bucais frente às bactérias orais. Os resultados mostraram que os enxaguantes apresentaram efeito antimicrobiano heterogeneo. Sessenta e nove por cento dos enxaguatórios apresentaram atividade antimicrobiana frente a todas bactérias, sendo os mais efetivos: Periotrat ${ }^{\circledR}$ e Periogard $\AA$. Concluimos que a maior parte dos enxaguatórios comerciais foi capaz de inibir o crescimento bacteriano.

\section{Palavras-chave:}

Enxaguantes bucais, atividade antimicrobiana, bactérias orais

\section{Introdução}

Estudos recentes estimam que centenas de bactérias diferentes fazem parte da microbiota oral ${ }^{1}$. Estas bactérias podem resultar em efeitos nocivos quando se fixam aos dentes ${ }^{2}$. Buscando auxiliar a eliminação destas bactérias, surgiram os enxaguatórios bucais, que por apresentarem componentes antimicrobianos em sua composição auxiliam na higiene bucal diária, reduzindo a formação do biofilme microbiano dentário ${ }^{3}$. Considerando a importância dos enxaguatórios na higiene bucal, este estudo teve por objetivo avaliar a atividade antimicrobiana de diferentes enxaguatórios bucais frente às bactérias orais.

\section{Resultados e Discussão}

Foi avaliada, em triplicata, a suscetibilidade dos microrganismos (Tabela 1) frente à 13 enxaguatórios bucais comerciais. O método utilizado no estudo foi o do disco de difusão em ágar (Figura 1).

Tabela 1. Microrganismos utilizados para avaliar a atividade antimicrobiana dos enxaguatórios

\begin{tabular}{|l|l|}
\hline \multicolumn{1}{|c|}{ Bactérias } & \multicolumn{1}{c|}{ Referencia } \\
\hline $\begin{array}{l}\text { Aggregatibacter } \\
\text { actinomycetemcomitans ( } \mathrm{Aa})\end{array}$ & INQS 78 \\
\hline Enterococcus faecalis $(\mathrm{Ef})$ & ATCC 29212 \\
\hline Propionibacterium acnes $(\mathrm{Pa})$ & INCQS 229 \\
\hline Porphyromonas gingivalis $(\mathrm{Pg})$ & ATCC 33277 \\
\hline Staphylococcus aureus (Sa) & ATCC 25913 \\
\hline Streptococcus mutans (Sm) & ATCC 700610 \\
\hline Streptococcus sanguinis (Ss) & ATCC 10556 \\
\hline Tannerella forsythia (Tf) & ATCC 43037 \\
\hline & \\
\hline
\end{tabular}

Figura 1. Método de disco-difusão em ágar. A - Cultivo e Isolamento das espécies; $\mathbf{B}$ e $\mathbf{C}$ - Padronização da concentração utilizando a escala McFarland 0,5; D e E - Plaqueamento dos espécimes; F-Inserção dos discos de papel de filtro estéreis; G Impregnação com enxaguatório.

Em nosso estudo, observamos que:

> Sessenta e nove por cento dos enxaguatórios apresentaram atividade antimicrobiana frente a todas bactérias (Figura 2);

$>$ As bactérias mais resistentes foram: Propionibacterium acnes, Streptococcus mutans e Enterococcus faecalis (Figura 3);

$>$ Os enxaguatórios apresentaram efeito antimicrobiano heterogêneo (Figura 4);

$>$ Os enxaguatórios que apresentaram maior atividade foram: Periotrat $\AA$ e Periogard $\AA$ (Figura 5).

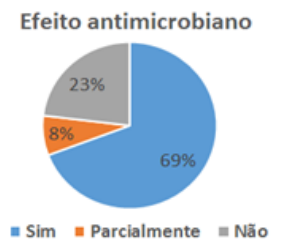

Figura 2 - Atividade antimicrobiana dos enxaguatórios

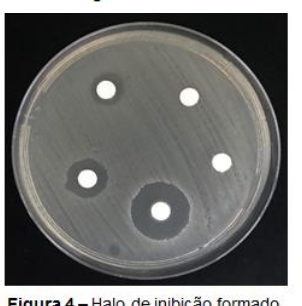

Figura 4-Halo de inibičão forma por diferentes enxaguatórios

ofeito antimicrobiano heterogêneo dos enxaguantes está relacionado aos diferentes princípios ativos e concentrações. Periotrat® e Periogard® são os únicos enxaguantes bucais avaliados que apresentam em sua composição $0,12 \%$ de gluconato de clorexidina, sendo os mais efetivos.

\section{Conclusões}

Concluímos que a maior parte dos enxaguatórios comerciais inibiu o crescimento bacteriano, sendo os mais efetivos: Periotrat ${ }^{\circledR}$ e Periogard $\AA$.

\section{Agradecimentos}

PIBIC - EM; CNPq (308162/2014-5); FAPESP (2015/23479-5); CAPES \& FAEPEX

1 - Gomes BP, Berber VB, Kokaras AS, ChenT Paster BJ. J Endod. 2015; 41 (12):1975-84 2 - Endo MS, Martinho FC, Zaia AA, Ferraz CCR, Almeida JFA, Gomes BPFA. Eur J Clin Microbiol Infect Dis. 2012; 31: 2575-83.

3 - Semenoff, T A D V, Semenoff-Segundo, A.; Biasolli, E R. . Revista Odonto Ciência, Porto Alegre, v. 23, n. 4, p. 351-354, 2008. 